DOI: $10.30842 /$ ielcp230690152454

\author{
A. V. Zhugra \\ (Institute for Linguistic Studies, RAS, St. Petersburg)
}

\title{
FIGURE OF THE NARRATOR IN ALBANIAN EPOS
}

The article addresses the issue of the way the representing the figure of the narrator is represented in the Albanian epos. One of characteristic traits of the Albanian epos, the use of dativus ethicus, allows the narrator to present himself as a direct witness of the described events and emphasize his presence, almost as a passive participant (one who observes, reflects, sympathizes).

The narrator's explanatory remarks are intended to render his narrative more understandable to the reader; they summarize the described event or orient the reader towards perception of the subsequent action.

These numerous rhetorical interrogative and exclamatory (imperative) remarks play an important role in the construction of the epic text, functionning as a boundary between two episodes. They also are a mark of the narrator's personal interest in the epic world he depicts.

Keywords: epos, Albanian, narrator, dativus ethicus, remark.

А. В. Жугра

(Институт лингвистических исследований РАН, Санкт-Петербург)

\section{Личность нарратора в албанском эпосе}

В статье рассматривается вопрос репрезентации фигуры повествователя в албанском эпическом тексте. Характерная черта албанского эпоса - дательный этический - позволяет повествователю выступать в роли свидетеля описываемых событий и проявлять себя почти как их пассивный участник (наблюдающий, размышляющий, сопереживающий). Пояснительные ремарки повествователя направлены на то, чтобы сделать повествование более понятным слушателю, они кратко резюмируют описанное событие или ориентируют на восприятие последующего.

Многочисленные риторические вопросительные и восклицательные (императивные) ремарки участвуют в построении эпического текста, оформляя границы отдельных эпизодов. Они также показывают заинтересованное отношение повествователя к изображаемому эпическому миру.

Ключевые слова: эпос, албанский, повествователь, дательный этический, ремарка.

\section{Introductory remarks}

Albanian epic songs recount heroic deeds of the brothers Muji and Halili and their band of thirty warriors; they also mention other heroes that do not belong to the band. The songs reflect "the 
ideology and everyday life of the late stages of a lineage based society, the tragic conflicts stemming from the dissolution of patriarchal foundations, the military exploits of the warrior bands, chets" (Desnitskaya 1987: 147). The main themes of the songs include protection of pastures, abduction of women, forays, rescue of captives, stealing an extraordinary horse, complicated dealings with mythological creatures - zanas and ores.

Studies of the Albanian epos have hitherto focused primarily on its ideological aspects - its origin, the content of the song, main themes and motifs. On the other hand, questions of "technical" nature concerning the actual process of performance, the type of storyteller, his creative freedom or lack of freedom, remained on the periphery of the researchers' interest. Nevertheless, observations of general nature give us a certain idea of the persona of the Albanian rhapsode and of his social status.

Performer. Songs about heroes, Kreshniks, were performed not by professional singers, but by ordinary people from the rural environment of North Albanian highlands. Rhapsodes "display their mastery not for material incentives, but sing when the opportunity presents itself, in the family or among friends, in their own fis or in other fises that they attend on the occasion of family and public holidays" (Sako 1966: 11). Singers have never used their mastery for personal enrichment and would not accept money or any other remuneration. This is echoed by the rhapsodes of today: ... kajkët githmonë ... i kam knue për qejf. Asht marre me lypë pare për me knue kajkë trimash 'My songs, I have always sung them for pleasure. It is shameful to ask for money for singing about heroes'; Në anët tona kajka asht kndue gjithmonë për qejf e gëzim, ndonjiherë për të zbutë dëshpërimin e hallet, por ajo nuk asht kndue kurrë për të fitue pare 'In our land, a song has always been performed for pleasure and joy, sometimes to alleviate despair and grief, but never has it been sung for money' (Neziri 2016: 318).

Both the singer and his audience view the performance of songs about Kreshniks with outmost seriousness. In a highlander's eyes, it is not entertainment, but an educational act which also provides aesthetic pleasure. The singer performs in an environment he knows well, among his friends, relatives and acquaintances. There is a complete mutual understanding and a close emotional connection between the singer and the audience, and the silence that reigns in the room during his performance is almost religious.

A necessary part of the performance of epic songs has always been the accompaniment on the lahut (lahutë), a single-string bowed 
instrument that could be found in virtually every house in the highlands. That is why the Albanian rhapsode is called lahutar 'lahutar', i. e. 'the lahut-player'. The Albanian epic song as a composition exists solely as a unity of its verbal and musical embodiment. These two aspects of the performance are so interconnected that "two voices resound, but one is also uttering words".

This article examines the demeanour of the Albanian rhapsode from what he reveals about himself in his epic. This study was conducted on the texts included in the anthology "Legendary Epics" (Epika 1966) — one hundred songs amounting to almost 20,000 verses.

\section{Narrator in the folklore text}

We shall approach the analysis of the text and the role that narrator plays in it from the point of view of linguistics of narrative as developed, in particular, by E. V. Paducheva in her works. The language of narrative differs from the spoken language above all with regard to "the context of communication in which the message is transmitted from one subject to another", and this context of communication is characterized as imperfect or non-canonical (Paducheva 1995: 41, 43). The author of a work of fiction has to be distinguished from a person who is speaking in a conversation: first of all, he is separated (in time and space) from his statement, and secondly, he does not belong to the world of the text that he is creating. That is why, in the context of the narrative, the speaker corresponds "not to its author, but $<\ldots>$ to its narrator: the narrator is the conscious subject that is directly embodied in the text, and that the reader is confronted with" (Paducheva 1996: 201-202). The narrator is the author's representative in the text, and he "has the image that the actual author wished to bestow on him" (Paducheva 1995: 40).

Albanian heroic epic songs are oral poetic works that recount events that occurred in bygone times. As such, the epic song is a narrative; like in any narrative, it has a narrator or a storyteller, i. e. an authority that organizes the text of the song from the point of view of both expression and composition. However, in a folklore text the relationship between the narrator and the author is much more complex than in a work of literature.

Folklore compositions in general, and the heroic epos in particular, belong to the realm oral composition, so that their 
authentic existence is restricted to the moment of their performance by a rhapsode. At the same time, the art of rhapsode, in keeping with the conception of M. Parry and A. Lord, is "composition in performing". Speaking of the art of an epic singer, B. N. Putilov highlights two points. Firstly, "in his consciousness, the bylina is conceived as a narrative in its integrity, with its plot, characters, composition. Every verse in it is a link in the creation of a narrative in its wholeness, in the movement of a unified narrative..." (Putilov 1966: 231-232). Secondly, "verse of the bylina is in reality created by each new singer anew, and is reproduced with each new performance with different variations" [ibid.: 237].

The context of communication in which the rhapsode recreates the text of an epic song is close to the canonical context, but not identical to it. The performance of an epic song is an act of communication that requires the presence of the speaker and the listener who are in a fairly close visual contact, so as to see each other. However, communication in this case is unilateral, i.e. it is directed only from the speaker towards the listener, while no verbal response during the performance of a song is expected. When recreating his own version of a song, the singer is in fact creating it in front of his audience, stringing one verse after another, without the option of pausing and correcting himself.

What is then the rhapsode's role in this communicative situation from the point of view of linguistics of narrative? Being the speaker, he acts as a narrator with relation to the "imaginary" text he is reproduces, so that he is a kind of "speaking narrator" (we will designate him as Narrator 1). At the same time, the rhapsode introduces (or at least may introduce) new elements into the text of the song, and thus acts as the author of the work that is being performed.

However, once we start studying the recorded text of an oral composition as an epic narrative, we find ourselves in a noncanonical context of communication where the author and his composition are separated in time and space. Authorial changes that had been introduced into the text by the actual singer as it was being performed of the song, have fully been integrated into the epic song, are woven into the fabric of the narrative and are inseparable from it. The actual singer leaves his representative, Narrator 2, in the text, whose his verbal part coexists with the part of Narrator 1. The correlation of these two voices depends on the creativity and virtuosity of the rhapsode.

Scholars have already drawn attention to the complexity of the figure of the narrator in a folklore text. This issue has particularly 
been addressed in the domain of Russian heroic epic songs (bylinas). In folklore, the narrator takes form of a generalized figure of a collective creator and performer of epic bylinas, but at the same time, behind this generalized figure stand actual singers in whom this figure is embodied (Artemenco 1998: 189-190). The epic text reflects both Narrator 1 as the epic singer and Narrator 2 as the executant of the narrative function. The objectivity of the epic narration is regularly breached by continual insertion of elements of subjective assessment, for example, words with subjective assessment suffixes and connotative words (the young Dobrynyushka, but: the foul Tatar), by the characters representing themselves in direct speech using the third, not the first, person, etc. [ibid.: 193).

With regard to the Albanian material, it should be noted that this article will focus only on two types of the numerous ways the narrator can manifest his presence in his text - on the use of the dativus ethicus, as well as on various insertions in the narrative. Despite the different functions that these phenomena carry out in the text, they are due to one cause in that they result from the canonical context of communication in which epic songs were performed, or, to put it differently, they should be attributed to Narrator 2 .

\section{Dativus ethicus}

Dativus ethicus, or dative expressive, or dative of ethic participation, is well represented in different European languages. Its use is lexically limited, as it is restricted to forms of personal pronouns. At the core of this phenomenon lies the speaker's wish to indicate his involvement in the situation he is describing: "Dativus ethicus includes in the utterance in which a given situation is described a person, usually one of the participants of the verbal act (that is, one of the parties in the context of communication), and thereby engages this person in the situation described, despite his being in no way involved in it inasmuch he is not its actual participant" (Kustova). The dative is characteristic, first of all, of colloquial speech, of a dialogue, and it is used to express the speaker's perspective, conveying his emotional reaction to and his moral assessment of the information that is introduced.

The role of dativus ethicus in Albanian epic songs varies depending on whether it is used in the author's narrative or in the characters' speech. Heroic songs of the Albanian epos are an oral composition in which the narrator's (or "author's") speech, related in the third person, and the characters' direct speech (i. e. the voice 
of the other) are combined. In quantitative terms, in the Albanian epos, authorial speech only slightly surpasses the characters' direct speech (the latter constitutes on average $44 \%$ of the text of the song).

The narrator does not indicate his presence explicitly in his narrative, nor does he indicate his sources of knowledge about the events he recounts. Given his impersonal stance, the narrator cannot directly express his opinion of his characters and their actions. But at the same time, the narrative contains linguistic data that indicate indirectly both the source of narrator's knowledge of the epic past and his view of it.

Analysis of the use of dativus ethicus in Albanian epos showed that it primarily occurs in the authorial narrative (875 examples), and that it functions mainly as a marker of evidentiality, presenting the narrator as a direct witness of the events he describes (Zhugra 2018). Once the dativus ethicus is incorporated within the narrative text, it acquires a new usage, suggesting that the speaker witnessed these events ${ }^{1}$.

In the following sections we intend to add some new observations and data to the what has been established about the use of dativus ethicus as a marker of evidentiality.

\section{Narrator as witness}

The narrator in Albanian epos often positions himself as a witness to the described events. In such cases, the narrative becomes more subjective and acquires certain traits characteristic of storytelling, and the narrator himself becomes a storyteller to a certain degree. In this guise, the narrator "either tells his own story, or relates the events that he had himself observed" (Paducheva 1996: 205).

In this context, the use of dativus ethicus in a song is optional and depends entirely on the narrator's will. However, preference is given to particular lexical verb groups and certain scenes and actions of the characters. Most often, dativus ethicus appears with verbs of speech that introduce the characters' direct speech, as well as with verbs of movement.

The list of verbs that can be used to introduce direct speech in the epic text is quite extensive, and dativus ethicus can can be used

\footnotetext{
${ }^{1}$ Constructions with dativus ethicus in characters' direct speech (170 examples in total) retain the dramatic expressivity that characterizes their use in colloquial speech.
} 
with any of them. The most frequent is the formular expression qet 'I extract' $+e$ 'and '+ them 'I say' (which is semantically close to Russian изрекать 'to utter'). Thus, in the song "The Death of Desdar Osman Aga" (80 verses) seven of eight expressions introducing direct speech contain a dativus ethicus, and five of them in the form of this formular expression: Se ç'ka qitë motra e m'i kish thanë (47: 31) 'What to me (dativus ethicus) the sister uttered (literally, 'extracted and told') to him'; the formula is repeated in four other verses $(47: 6,37,39,42)$.

The frequency of dativus ethicus with verbs of speech must be connected to the role that these verbs play in structuring the epic text by indicating the introduction of direct speech. It is also surely due to the close the fact that verbs of speech, by virtue of their semantics, are close to the domain of evidentiality. Thus, indirect evidentiality inherent to the verb them 'to speak, to say' is somewhat neutralized by direct evidentiality expressed by the first person dativus ethicus.

Similarly, verbs of movement tend to appear at important junctures in the development of a plot. The use of dativus ethicus with them reflects the narrator's wish to emphasize the credibility of his account and to highlight the importance of the event for the plot.

When used with other predicates, dativus ethicus allows the narrator to reveal other facets of his personality, by manifesting himself as the perceiving subject, the conscious subject, or the emotional subject. Examples of this kind are much less frequent, but they reflect the narrator's use of dativus ethicus as an artistic device.

\section{Rhapsode as observer}

As noted earlier, the core function of dativus ethicus in the epic narrative is to present the speaker as a witness to the described events. In cases when the predicate of the phrase describing a given situation is expressed by a verb of perception (for example, visual perception), dativus ethicus indicates the speaker as the perceiving subject.

The use of dativus ethicus is revealing in the case of verbs shikoj, kqyr 'to look' and shoh 'to see'. For example, in the song "Martesa e djalit jabanxhi me vajzën e Kurt Agës" ("Wedding of a Young Foreigner and the Daughter of Kurta Aga"; 25:211-226) Muji, as he is about to enter into battle, and inspects the surroundings through a monocular: he looks at the part of the bridge that is closest to him ( $k a$ shikjue at ballin e urës), then looks beyond (Ma andej po kqyrë), and then even further (Ma andej shikjon); in 
each case, the verb meaning "to watch" is used without dativus ethicus. But in the phrases describing what he sees, the verb shoh (perfect $\mathrm{ka} \mathrm{pa}$ ) is accompanied by dativus ethicus of the first person pronoun: E ma shef Burc Eleze Krajlin. I Nji mijë vetë me vedi i ki' marrë 'and to me (dativus ethicus) he sees Burc Eleze Krajlin / a thousand men he brought with him', ma ka pa at Sminaliqe Savin, I Tri mijë vetë me vedi i ki' marrë 'to me (dativus ethicus) he saw this Sminaliqe Savin / three thousand men he brought with him', po ma shef Gjuron Harambash, / Pesë mijë vetë me vedi i ki' pa' marrë, 'to me (dativus ethicus) he sees / five thousand men he brought with him'.

Dativus ethicus of the first person pronoun with the verb shoh 'to see' indicates that in these contexts the narrator appears as the perceiving subject (the action is directed from object to subject). The narrator appears to see the same 'thousands of men', as Muji, he is transferred into the world he describes (the narration is made from the third person, as indicated by the verb form sheh). In such contexts, the omniscient narrator exterior to the events he describes coexists with the narrator who is their direct witness.

The narrator may also appear as an observer in description of objects or some static situations. Epic songs may supplement the account of events by a static description that characterizes an object, a character, a locality, or list a sequence of actions in a given minisituation. The general narrative in these cases is suspended, and we are presented with a picture, a mini-plot limited spatially and chronologically. For example, in the song "Halili merr gjakun e Mujit" ("Halili retaliates for Muji"), after Muji has been seriously wounded, Dizdar wants to examine his wounds. The description comprises 26 verses where dativus ethicus is used 9 times, appearing even at the very beginning of the fragment, as Muji folds back the blanket, and arrët e shtatit Muji m'i ka zbulue (24: 149) "wounds on Muji's body did he reveal to me (dativus ethicus)". From the very beginning of the description, the speaker (narrator) is indicated as being present at this scene.

The narrator-observer can also appear in the text as a conscious subject, especially with verbs semantically associated with unexpectedness. Epic heroes will often find themselves in situations that or unexpected for them and/or for the narrator. Descriptions of such situations regularly include the verbs qilloj 'to strike, to hit; to accidentally find oneself in a place or in a particular state' and $n d o d h$ 'to happen; to find oneself by chance in a given place'. As is typical of the Russian verb оказаться 'to find oneself', in these 
cases "the sign is not presented as open, ready to be perceived, but as a sign yet to be opened, to be discovered through a certain effort on behalf of the observer, or, contrary to his expectation, by transcending a certain boundary between the object and its sign" (Zolotova 1973: 219). This observation equally applies to a situation where the localized presence of an object turns out to be unexpected.

Verbs denoting an "unexpected detection of something" suggest the existence of an external observer, i. e. a conscious subject who perceives this new information but is not explicitly present in the auctorial narrative. The narrator is explicitly identified as this implied external observer by use of dativus ethicus of first person pronoun (singular or, more seldom, plural). Thus, when describing the heroes' combat, the narrator points at an unexpected hindrance: Aty m'ndodhi 'i cung $i$ zi (6: 424) 'and suddenly to me (dativus ethicus) a black stump appeared', or when the heroine expresses her feelings too freely, E ama ngjat m'i ka qillue / nji shuplakë ftyrës çikës ja ka dhanë (23: 43-44) 'Her mother to me (dativus ethicus) happened to be next to her, / she slapped her daughter in the face'.

In these and similar contexts, the discovery of a certain object or person is presented as unexpected for the narrator, and the wording not only states the fact of presence, but also the narrator's surprise at this fact, carrying an element of subjectivity.

\section{Rhapsode as sympathetic witness}

Songs often state the feelings that epic heroes experience in difficult situations, their emotional reaction to tragic or, on the contrary, joyful events. In describing such situations, the following verbs are used: ngushtohem 'to grieve', idhnohem 'to feel sad', frigohem 'to get frightened', i vjen mire / keq 'to feel well / unwell', terbohem 'to become furious (enraged)', behem me qejf 'to come in a pleasant state of mind', dhimbet 'to feel pity', etc.

In the cases when the predicate is accompanied by the dativus ethicus, the narrator is presented not only as a witness, but almost as a participant of the situation, sympathizing with the hero.

Sa fort Muji m'asht tërbue! (4: 658) 'How angry to me (dativus ethicus) did Muji become!'; Por Halili aty ma s'â pa, / kaq fort djali m'ite kenë idhnue! (24: 226-227) 'But Halili is no longer here, / so upset to me (dativus ethicus) did this young man get!'. These statements deal with heroes that are revered and deeply admired by the rhapsode, therefore it is possible to postulate that dativus ethicus carries a semantic nuance possessiveness (cf. "How angry did my Muji become!"). 
However, similar statements are also found in relation to the heroes' opponents, to the krajli and shkja: Sa keq krajlit m'i ka ardhë, I nji sahat krajli nuk ka folë! (22: 45-46) 'How distressed did Krajli to me (dativus ethicus) feel, / Krajli did not speak for an entire hour'.

In all these cases, the representation of the narrator as a witness to the events he is describing is indicated by the use of dativus ethicus which appears to be superimposed on the auctorial narrative structure of the sentence: this may even be perceived as a kind of contradiction, given the occurrence in one narrative of the first and the third person. However, this contradiction is purely formal, and is revealed only through linguistic analysis. In an epic text dativus ethicus serves as a means for the narrator to enliven his narrative, bringing the events vividly before his audience's eyes.

\section{Remarks}

The other feature typical of the Albanian epic text is the presence of insertions that function as a kind of remark or commentary on the part of the narrator. As a general rule, these remarks are short, no longer than a line, insertions in the authorial text, that indicate to a certain degree his perspective. Such insertions are due to the actual context of performance, the life of a folklore composition. A similar feature has been noted for Russian bylinas by A. M. Astakhova (Astakhova 1951: 691-694): she identified three types of remarks - explanatory remarks, that were meant to help the audience to understand realia of olden days, narrative (or epic) remarks, that were connected with the very plotline, and lyrical remarks, ones, that characterized the narrator's own personality.

Remarks coming from Albanian narrators are in many ways similar to the remarks that can be found in Russian bylinas, however they are characterized by their own unique traits of expression and specific ethnic colouring.

Explanatory remarks are extremely rare in the Albanian epic songs (some rare examples relate to "miraculous" phenomena, for example, a talking raven - se gjithsendi m'at vakt po folke [28: 115] 'because in those days any [beast] could speak'). We do not single out these remarks as a separate type because of their scarcity.

Narrative remarks in the Albanian epics are woven into the fabric of the narrative, they are intricately connected to the development of the plot, and often occupy the initial, final or middle position within a single episode. The position of the remark depends 
on the goal set by the narrator, whether it be to explain an event that came to pass, to insert his own conclusion, to present a reason for what is yet to happen, or to explain in passing a certain situation, without interrupting the flow of his narrative. The narrator may even use an insertion of this kind for a humorous side remark: for example, as his, hero dressed in Hungarian clothes, puts on a belt and sets out to travel, the narrator quips: për gjynah zoti mos ja shkroftë (86: 359) 'May God not consider this a sin'.

Lyrical (emotional) remarks are the remarks that reflect the narrator's personal poetic vision of the world. For example, the song "Muji and Behuri" describes the tragic fate of the warriors are separated from the band. Two young heroes are to part, and one of them will die. On the eve of the parting, they do not sleep all night, watching zanas gurrave po këndojnë ... e po lodrojnë 'sing... and dance near the springs', as they po mbledhin lule fushave 'pick flowers in the fields' and po ndiellin dhit-o 'gather together [their] goats'. This idyllic picture concludes with the remark Nata $e$ shndreut me ngiatë sall nji dekik! (6: 87) 'St. Andrew's night lasts but a moment!'. With these words the narrator introduces an alarming psychological nuance in the description of the night that corresponds to the feelings of both the heroes and his own. The heroes wish the night to last longer, they adjure the moon to linger in the sky; the narrator, on the other hand, knows the future, he is full of sympathy for the heroes, and forewarns the listener of what is to come.

Text structuring remarks. The role of remarks in the narration has already been described, but it seems appropriate to single out a group of remarks in which the narrator appears as the subject of speech. These are rhetorical questions and exclamations with the predicate often expressed by imperative and optative forms. These direct addresses to the audience play an important part in the structuring of an epic text, as they are linked to the transition to a new character or to a new action and help to outline the boundaries of the episodes.

a) Remarks as a way to introduce the characters' direct speech

The Albanian epos offers a broad variety of ways to introduce direct speech, from the neutral, widely used formula $\mathrm{ka}$ qite $\mathrm{e} \mathrm{ka}$ thane 'took out and said', to complex structures that contain a vivid characterization of characters. Interrogative and exclamatory imperative sentences are common in this kind of introductions of direct speech. 
Interrogative sentences of this kind are built on the model: "What did he (they) say...?", often with a characteristic of the character. Shka ka thanëe nji plak $i$ urtë? (23: 98) 'What did the wise old man say?'; Shka i ka thanëëe baxhija e shkretëe? (10: 104) 'What did the honoured lady tell him?', Ça kanëee thanëee agët $e$ ngujuem? (16: 85) 'What did the imprisoned Ags say?', Në letër kralit ç'i kish thanëëe? (86: 141) 'What did he say in the letter to Krajli?', etc.

The same formula ka qitë $e$ ka thanë 'took out and said' that is regularly accompanied by the dativus ethicus, often appears in interrogative sentences introducing direct speech. In some songs, the use of this formula (with slight variations) seems excessive and even monotonous. For instance, in the song "Ali Bayraktari" (141 verses) the formula $E$ ç'ka qitë s'amës $i$ ka thanëee? 'And what did he take out and say to his mother?' is found fourteen times $(75: 15,33,36$, $42,58,63,65,68,77,104,107,109,124,136)$.

Exclamative (imperative) sentences introducing the heroes' direct speech are built on the model "Just fancy what he (they) said...". Kqyre Radi krajlit çka $i$ ka thane (19:245) 'Just fancy what Radi said to Krajli'; Kqyr çka foli Gjeto Basho Muja! (22: 188) 'Just fancy what Gjeto Basho said to Muji', Kqyre krajli atherë çka i ka thanëee! (22: 259, 302) 'Just fancy what Krajli said to him in response', etc.

b) Remarks as transition to a new episode in the narrative

Interrogative and exclamatory (imperative) sentences, as means to pass to a new episode, include a verb with the meaning "to do" (following the model "What did X do?" / "Look at what X did!"). They may be accompanied by evil or good wishes that express the speaker's emotional attitude to the described event, e.g. anger against the heroes' opponents: Shka bani krajli, o zoti e vraftë! (63: 25) 'what did Krajli do, may God kill him!'. This formula is repeated in a number of songs, Shka bani krali, zoti e vraftë? (89: 55) 'Look what Krajli has done, may God kill him!' (92: 117; 94: 62 ), and may even be repeated multiple times within the same song, with slight variations.

\section{Conclusion}

In Albanian epic texts the narrator does not appear exclusively as a neutral omniscient storyteller. In many passages, the presence of a different figure, Narrator 2, is also felt, and this figure may be identified with the rhapsode who is performing the song. Linguistic 
manifestations of Narrator 2 are a result of his consideration for his audience and of his desire to present his narrative as credible, understandable and well structured. The epic narrative, while remaining predominantly auctorial, becomes then more lively, peppered with elements of subjective assessment, while insertion of direct address to the listener renders the narrator to some extent the author of the story he is recounting. The narrator's direct remarks also attest to his interest in the epic world he depicts.

\section{References}

Artemenco, E. B. 1998: [The narrator's problem and its linguistic representation in folklore (based on epic material)]. Filologicheskie zapiski: Vestnik literaturovedeniya $i$ yazykoznaniya. Vyp. 11. Voronezh: university, 186-195.

Артеменко, Е. Б. 1998: К проблеме повествователя и его языковой репрезентации в фольклоре (на материале былинного эпоса). Филологические записки: Вестник литературоведения и языкознания. Вып 11. Воронеж: Воронежский государственный университет, 186-195.

Astakhova, A. M. 1951: Bylinas of the [Russian] North. Vol. II. Moskva; Leningrad.

Астахова, А. М. 1951: Былины севера. Т. ІІ. М.; Л.

Desnitskaya, A. V. 1987: Albanian literature and Albanian language. Leningrad: Nauka.

Десницкая, А.В. 1987: Албанская литература и албанский язык. Л.: Наука.

Elsie, R. A Dictionary of Albanian Religion, Mythology and Folk Culture. New York University Press.

Folklor shqiptar, II. 1966: Epika legjendare (Cikli i kreshnikëve). Vëllimi i parë. Tiranë, Instituti i folklorit.

Kustova, G. I. Dative case. Data for project of Corpus Studies of Russian grammar (http://rusgram.ru).

Кустова, Г. И. Дательный падеж. Материаль для проекта корпусного описания русской грамматики (http://rusgram.ru). На правах рукописи. М.

Neziri, Z. 2016: Figura e rapsodit shqiptar dhe çështja homerike. In: Eposi $i$ kreshnikëve: monument i trashëgimisë kulturore shqiptare. Vëllimi I. Prishtinë, 305-323.

Paducheva, E. V. 1995: [V. V. Vinogradov and science of fiction language]. Izvestiya Akademii nauk RAN, seria literatury $i$ yazyka. T. 54.3, 39-48.

Падучева, Е. В. 1995: В. В. Виноградов и наука о зыке художественной прозы. Известия Академии наук РАН, серия литературы и языка. Том 54, № 3, 39-48.

Paducheva, E. V. 1996: Semantic research. Moscow.

Падучева, Е. В. 1996: Семантические исследования. М.

Putilov, B. N. 1966: [The Art of the Singer of Bylinas: Textological Observations on the Bylinas]. In: Principy tekstologicheskogo 
izucheniya folklora. [Principles of textological studies of Folklore]. Moscow-Leningrad, 220-260.

Путилов, Б. Н. 1966: Искусство былинного певца (из текстологических наблюдений над былинами). В сб.: Принципь текстологического изучения фольклора. М.; Л.: Наука, 220260.

Sako, Z., Haxhihasani, Q. 1966: Hyrje. In: Folklor shqiptar, II. Epika legjendare (Cikli i kreshnikëve). Vëllimi i pare. Tiranë, 7-49.

Zhugra, A. V. 2018: Dativus Ethicus in Albanian epic texts. Indoevropeiskoe yazykoznanie i klassicheskaya filologiya 22(1), 499-518. Жугра, A. B. Dativus Ethicus в албанском эпическом тексте (некоторые наблюдения). Индоевропейское языкознание и классическая филология 22(1), 499-518.

Zolotova, G. A. 1973: Essay on the functional syntax of the Russian language. Moscow.

Золотова, Г. А. 1973: Очерк функиионального синтаксиса русского языка. Москва. 